\title{
Quantitation of G-cells in fibreoptic biopsy specimens and serum gastrin levels in healthy normal subjects
}

\author{
J. PIRIS AND R. WHITEHEAD \\ From the Department of Pathology, Radcliffe Infirmary, Oxford
}

SYNOPSIS The G-cells of the gastric antrum were accurately quantitated in preparations stained with an immunoperoxidase method. In 15 normal young adults the mean G-cell count per unit area was $200 \pm 15 \cdot 9$. Serum gastrin levels were measured in 12 , and all fell within the normal range (mean $59 \cdot 7 \pm 5 \cdot 4 \mathrm{pg} / \mathrm{ml})$.

It is well recognized that the level of serum gastrin is greatly altered in some forms of gastroduodenal disease. The main source of gastrin is the so-called G-cell of the gastric antrum. A definitive study of the number and distribution of these cells in the normal human stomach has not been made.

This paper presents the results of such a study and is based on biopsy material obtained by fibreoptic endoscopy in a group of 15 healthy young adults.

The G-cells were demonstrated by an immunoperoxidase method which permits the best possible quantitation for reasons discussed elsewhere (Piris and Whitehead, 1974). In the majority of the subjects serum gastrin levels were measured by radioimmunoassay.

\section{Material and Methods}

Eleven young adults submitted themselves for examination. Adequate histological material was obtained in nine. Two of these showed evidence of gastritis and were excluded.

Eight further young adults were examined by endoscopy for various vague clinical symptoms including abdominal pain. All had normal gastroscopic appearances, a normal barium meal, normal gastric secretory function tests, normal levels of folate and vitamin B12 and, when measured, normal serum gastrin levels.

The endoscopy was performed after an overnight fast, and at the same time a sample of blood was taken and the serum separated and stored at $-20^{\circ} \mathrm{C}$. The gastrin was estimated by radioimmunoassay using a gastrin Immutope kit (Squibb and Son Inc.).

One or two biopsies were obtained from a standard

Received for publication 10 March 1975. site in the antrum on the lesser curve between the incisura and the pyloric ring. This site was chosen because of the usual distribution of the antral mucosa in the normal stomach (Whitehead, 1973). It occurred to us, however, that the distribution of G-cells may not be uniform throughout the whole area of the antrum. Operative specimens altered by disease could clearly not be used to test this point and so one of us (J.P.) volunteered to have multiple antral biopsies taken from the whole of the pyloric area, a total of 12 in all. In fact the G-cells appeared evenly distributed but the possibility must remain that some variation in population occurs in the antrum of other subjects.

The fixation and staining method has already been referred to (Piris and Whitehead, 1974). Care is taken that the blocks are embedded in such a way that sections are cut perpendicular to the muscularis mucosae. Counts were made only on those biopsies in which this was present.

The final preparation is one in which the cytoplasmic granules of the G-cells are stained dark brown and the background tissues, whose structural features are well shown, appear a light green.

\section{QUANTITATION}

A morphometric method which would give reproducible and acceptably accurate results had to be specially designed. Certain factors determined the final method chosen. A Leitz microprojector was used to project the tissue sections onto an adjacent screen and the lens system $(\times 25$ objective and $\times 2$ ocular piece) at a screen distance of 1 metre gave a final magnification of $\times 580$. This allowed easy recognition of positive G-cells but also the tissue structures. A grid (figure) was pinned to the screen and so designed that at the magnification used the 
points on the grid are clearly visible, and they were distributed at a density which allowed for the minimum of difficulty in counting a sufficient number of them. Because the points of the grid are uniformly distributed it is important that the section is cast on the grid so that the first field is chosen at random. By moving the microprojector stage systematically the complete section is scanned and care is taken that each area is assessed only once. The muscularis mucosae is used as a reference point to ensure that the full thickness of the mucosa is covered; this is the rationale for excluding any biopsy which does not include it.

Grid points falling on the epithelium and on the lamina propria are counted as are the total number of G-cells. By counting an increasing number of points falling on the tissue section and the corresponding number of $G$ cells, a ratio of $G$-cells to points was obtained. This varied until 700 points were counted when it stabilized. The principle of summation average (Dunnill, 1968) dictates that this is the minimum number of points that should be counted, but for the sake of thoroughness at least 1000 points were counted in each biopsy. It was necessary to count sections at different levels through the block; to ensure that the same cells were not counted twice these levels were always separated by at least two intermediate sections.

It is extremely important, no matter how much the count of 1000 points is exceeded, that the whole of any section is counted. This ensures that there are

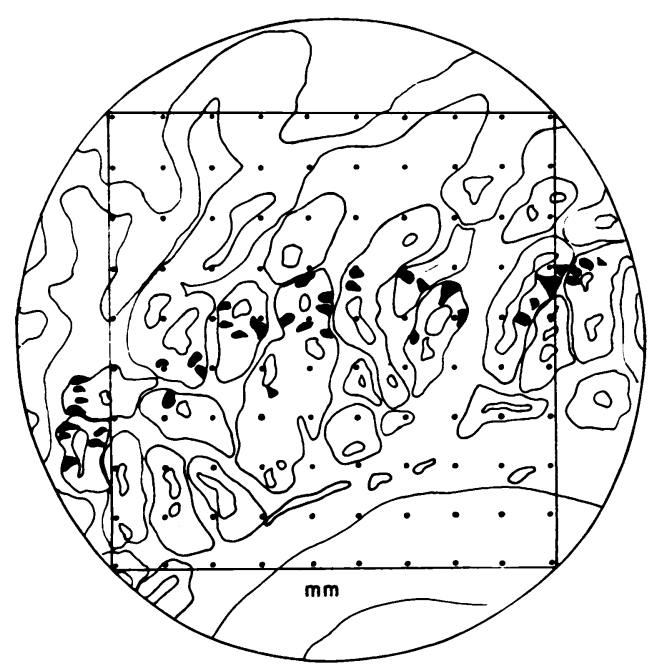

Figure Morphometric grid with diagrammatic representation of antral mucosa superimposed ( $m \boldsymbol{m}=$ muscularis mucosae). In this field, for example, number of points on tissue $=83$, number of $G$-cells $=25$. no errors due to uneven distribution of the G-cells within the mucosa.

The method described provides a means whereby the number of G-cells is related to a standard area of mucosa. This is because the number of points falling on the tissue is proportional to its surface area (Weibel, 1963).

\section{Results}

The G-cell counts are shown in the table and are presented as a ratio of the number of cells per unit area. The range is from $116-322 \mathrm{G}$ cells per 1000 points. No statistical difference was found, using Student's $t$ test for small samples, between the seven normal volunteers and the eight other subjects included in the group $(P>0.5<0.6)$. The mean G-cell count of the whole group was 200 with a standard error of $\mathbf{1 5 . 9}$. Analysis revealed no age or sex differences.

In the subjects whose serum gastrin was measured (12 out of 15) the values ranged from 33 to 95 picograms per millilitre $(\mathrm{pg} / \mathrm{ml})$ with a mean of $59.7 \pm 5.4 \mathrm{pg} / \mathrm{ml}$.

According to the manufacturers of the kit other workers have established a normal range of 50-155 $\mathrm{pg} / \mathrm{ml}$. Levels obtained by workers using other methods (Berson and Yalow, 1972; Korman et al, 1971; McGuigan and Trudeau, 1970) are slightly different.

Our experience with the same assay system gave an average level in 12 patients with pernicious anaemia of $776.25 \mathrm{pg} / \mathrm{ml}$ and in nine patients with gastric ulcer an average level of $205 \mathrm{pg} / \mathrm{ml}$. Both these, when compared with our normal range, are statistically highly significantly different.

\begin{tabular}{lllllll}
\hline $\begin{array}{l}\text { Case } \\
\text { No. }\end{array}$ & Sex & Age & $G$ & $A$ & $G / A$ & $\begin{array}{l}\text { Serum } \\
\text { Gastrin } \\
(p g / m l)\end{array}$ \\
\hline 1 & & & & & & \\
2 & M & 25 & 289 & 897 & $0 \cdot 322$ & 42 \\
3 & F & 24 & 417 & 2156 & $0 \cdot 193$ & 57 \\
4 & M & 34 & 278 & 1278 & $0 \cdot 218$ & 33 \\
5 & F & 20 & 192 & 1032 & $0 \cdot 186$ & 43 \\
6 & F & 22 & 120 & 1024 & $0 \cdot 117$ & 59 \\
7 & M & 32 & 184 & 1589 & $0 \cdot 116$ & 69 \\
8 & F & 17 & 351 & 1146 & $0 \cdot 306$ & 95 \\
9 & M & 43 & 267 & 1576 & $0 \cdot 169$ & - \\
10 & F & 41 & 383 & 1592 & $0 \cdot 241$ & 92 \\
11 & M & 27 & 238 & 1638 & $0 \cdot 145$ & 63 \\
12 & M & 31 & 228 & 1601 & $0 \cdot 142$ & - \\
13 & F & 53 & 307 & 1540 & $0 \cdot 199$ & 54 \\
14 & F & 31 & 434 & 1697 & $0 \cdot 256$ & - \\
15 & M & 21 & 470 & 2598 & $0 \cdot 181$ & 55 \\
\hline
\end{tabular}

Table $G$-cell counts $(G)$, total number of points $(A)$, $G$ to $A$ ratio, and serum gastrin levels in the 15 subjects studied. 


\section{Discussion}

There have been subjective estimates of an increase in the number of antral G-cells in acromegaly (Pearse and Bussolati, 1970), pernicious anaemia (Creutzfeldt et al, 1971), and the Zollinger-Ellison syndrome (Wilson et al, 1972; Polak et al, 1972; Cowley et al, 1973). The first attempt to have objective measurement of G-cell numbers was by Polak et al (1971) using a television image autoanalyser on transparencies of immunofluorescent preparations. However, the authors themselves commented on the difficulty in establishing a figure for the normal population using two controls, because of the variation in distribution of G-cells in the normals as opposed to cases showing hyperplasia when the cells were more evenly distributed throughout the mucosa. We have taken this variation in distribution into account in our methodology which does not require the sam€ sort of sophisticated and expensive equipment. By their method actual numbers of G-cells per unit of mucosa cannot be arrived at accurately.

Hyperplasia of G-cells was described in some cases of duodenal ulcer using terms such as 'numerous' compared to others described as having 'few' in a publication by Ganguli et al (1974). However, there is no mention of their assessment in the normal situation.

It is, therefore, plain that there is need for an accurate and reproducible quantitative method for estimating G-cells which uses relatively simple equipment. In addition it is clear that figures for an entirely normal control group are needed before meaningful comparison with abnormal groups can be made. The gastrin levels measured in the present group of cases is of value in corroborating their normality. The method described here is applicable to fibreoptic biopsy specimens despite their size.

We have confirmed that in the normal stomach G-cells are present only in the antrum, but an estimation of the number in other parts of the stomach in abnormal circumstances or in other parts of the intestine can be achieved simply by additional sampling.

We wish to thank Dr S. C. Truelove and his team for their cooperation in providing the biopsy material and serum. We also express our gratitude to Mrs $\mathrm{Y}$. Smart for her painstaking technical assistance and to Dr J. Anderson, of the Department of Biomathematics, Oxford University, who advised on the statistics and the accuracy of the methodology. We are indebted to Drs M. S. Dunnill and J. Skinner who contributed their advice freely on the morphometric method finally employed.

Mrs Elizabeth Harris gave patient and expert advice on the radioimmunoassay techniques for which we are grateful.

J.P. is supported by a grant from the Wellcome Trust.

\section{References}

Berson, S. A. and Yalow, R. S. (1972). Radioimmunoassay in gastroenterology. Gastroenterology, 62, 1061-1084.

Cowley, D. J., Dymock, I. W., Boyes, B. E., Wilson, R. Y., Stagg, B. H., Lewin, M. R., Polak, J. M., and Pearse, A. G. E. (1973). Zollinger-Ellison syndrome type 1: clinical and pathological correlations in a case. Gut, 14, 25-29.

Creutzfeldt, W., Arnold, R., Creutzfeldt, C., Feurle, G., and Ketterer, H. (1971). Gastrin and G-cells in the antral mucosa of patients with pernicious anaemia, acromegaly and hyperparathyroidism and in a Zollinger-Ellison tumour of the pancreas. Europ. J. clin. Invest., 1, 461-479.

Dunnill, M. S. (1968). Quantitative methods in histology. In Recent Advances in Clinical Pathology, Series V, edited by S. C. Dyke, pp. 401-416. Churchill, London.

Ganguli, P. C., Polak, J. M., Pearse, A. G. E., Elder, J. B., and Hegarty, M. (1974). Antral-gastrin-cell hyperplasia in peptic ulcer disease. Lancet, 1, 583-586.

Korman, M. G., Soveny, C., and Hansky, J. (1971). Radioimmunoassay of gastrin (The response of serum gastrin to insulin hypoglycaemia). Scand. J. Gastroent., 6, 71-75.

McGuigan, J. E., and Trudeau, W. L. (1970). Studies with antibodies to gastrin. Gastroenterology, 58, 139-150.

Pearse, A. G. E. and Bussolati, G. (1970). Immunofluorescence studies of the distribution of gastrin cells in different clinical states. Gut, 11, 646-648.

Piris, J. and Whitehead, R. (1974). An immunoperoxidase technique for the identification of gastrin-producing cells J. clin. Path., 27, 798-799.

Polak, J. M., Bussolati, G., and Pearse, A. G. E. (1971) Cytochemical, immunofluorescence and ultrastructura investigations on the antral G-cells in hyperparathyroidism. Virchows Arch. Abt. B., 9, 187-197.

Polak, J. M., Stagg, B., and Pearse, A. G. E. (1972). Two types of Zollinger-Ellison syndrome: immunofluorescent, cytochemical and ultrastructural studies of the antral and pancreatic gastrin cells in different clinical states. Gut, 13, 501-512.

Weibel, E. R. (1963). Principles and methods for the morphometric study of the lung and other organs. Lab. Invest., 12, 131-155.

Whitehead, R. (1973). Mucosal Biopsy of the Gastrointestinal Tract (Major Problems in Pathology, Vol. 3). Saunders, London.

Wilson, R. Y., Boyes, B. E., Stagg, B. H., Lewin, M. R., Polak, J. M., Pearse, A. G. E., Dymock, I. W., and Cowley, D. J. (1972). Antral G-cell hyperplasia with hypergastrinaemia producing a Zollinger-Ellison syndrome. (Abstract). Gut, 13, 848-849. 